\title{
70 A PROCEDURE FOR THE ANALYSIS OF INDUSTRIAL NETWORKS
}

\author{
Dario Antonelli, Brunella Caroleo, Teresa Taurino \\ Politecnico di Torino - Corso Duca degli Abruzzi, 24 - 10129 - Torino, ITALY \\ dario.antonelli@polito.it, brunella.caroleo@polito.it, teresa.taurino@polito.it
}

\begin{abstract}
This paper gives a presentation of a procedure for the analysis of industrial networks. An appropriate meta-model, specifically dedicated to SME networks, is introduced to describe the interactions among firms. The importance of considering both scientific studies and real industrial systems to make a proper analysis of a network is put in evidence, introducing two significant investigation tools. After a description of a logical arrangement of available information, a procedure useful to fully analyse an industrial network, using both data/information from existing SME networks and technical/scientific reports, is presented.
\end{abstract}

\section{INTRODUCTION}

Industrial networks and clusters of Small and Medium Enterprises (SME) represent the European way of aggregating enterprises to compete in a worldwide business market, leaving at the same time autonomy to each SME (Albino and Kuhtz, 2004; Picard and Toulemonde, 2003; Rosenfeld, 1995; Verwaal and Hesselmans, 2004).

Many theoretical contributions have conceptualized the distinctive features of these forms of industrial development, based on affiliation of small and medium sized firms in geographically delimited areas. Firms located in regional industry clusters (called also industrial districts, ID) are generally characterized by some distinctive features: (i) within the district there is a division of labor among firms, which promotes high levels of flexibility and productivity; (ii) high degree of specialization in one or few complementary industries; (iii) horizontal competition and vertical cooperation: the spatial concentration and strong complementarities among different units turn competition into a connective force among agents; (iv) a distinctive milieu that includes the local institutional infrastructure; (v) common marketing strategies.

The academic literature on the performance of ID has been mostly either of qualitative nature or too specific (not looking at the network as a whole).

Some papers concern the comparison of the performances of firms with respect to their belonging to a district. Signorini (1994) compares the financial and economic ratios of some firms belonging to the district of Prato to the average of woolen cloth manufacturers located outside the province. Fabiani and Pellegrini (1998) analyze the profitability and productivity ratios of firms belonging to IDs in comparison with a control sample of similar firms. These and other studies (MolinaMorales, 2001) confirm the hypothesis of positive externalities for SMEs belonging to IDs (in terms of ROE, ROI, etc.), but they are mainly concerning ID performance from economic point of view.

Antonclli, D., Carolco, B., Taurino, T., 2007, in IFIP International Federation for Information Processing, Volume 243, Establishing the Foundation of Collaborative Networks; eds. Camarinha-Matos, L., Afsarmanesh, H., Novais, P., Analide, C.; (Boston: Springer), pp. 649-656. 
ID performance must not be restricted to economic and financial perspective; an industrial district, in fact, is defined as "a socio-territorial entity, characterized by the active co-presence of a community of people and a population of industrial firms" (Becattini, 1990). This is the reason for which it is necessary to consider also the performance of an ID from the social viewpoint, in order to better understand the influence that the district has on the population into which it is immersed and to comprehend the effects on social's welfare. Paniccia (1999) analyses these concepts in her research, focusing on the interactions between the performance of IDs and population's welfare.

Another component it is necessary to take into account is the governance. A comprehensive review of different roles that governance should have in an ID is presented in Alberti (2001). Albino et al. (1999) investigate the relationship between the number of leading firms in IDs and the quantity of information shared. Lin et al. (2005) examine the relationships between supply chain features and organizational performances, on a qualitative point of view.

Regarding the operational structure component, a wide literature on Supply Chain performance analysis exists (Akif et al., 2005; Abu-Suleiman et al., 2005; Klejinen and Smits, 2003). Furthermore, some ascertained tools can be used, as an example the SCOR model (Supply Chain Council, 2006) or the Balanced Scorecard (Kaplan and Norton, 1992; Kaplan and Norton, 1993; Kaplan and Norton, 1996; Brewer and Speh, 2000). The difficulty of applying these tools to IDs consists in the lack of 'aggregated' KPIs, as those usually disposable from IDs.

In the last years the majority of SME clusters faced a significant reorganization. Among the possible reasons for their crisis there is the lack of investments in innovation, due to the lack of an effective governing board able to boost innovation to SMEs. Except for some cases, industrial clusters have not been able to evolve into "networks". These issues might originate in the problem that SMEs do not know how to operate and effectively manage in a "network of SMEs".

In this context, the Coordination Action CODESNET (CA project $n^{\circ}$ IST-2002506673, http://www.codesnet.polito.it) was born with the goal of giving an organization and interpretation of data and information collected from the industrial systems of European countries and concerning networks of enterprises for the sake of improving the ID knowledge about network management.

\section{A META-MODEL FOR ANALYSIS OF INDUSTRIAL NETWORKS}

In order to give a formulation useful for network analysis and evaluation, a conceptual model of a DESNET (DEmand and Supply NETwork) can be stated in terms of a graph of partially autonomous firms, that means firms which agree to be collaborative together, to have a high rate of reciprocal transactions concerning components and products, to share information and common services, to define together common industrial strategies (as in case of joint projects to search for a new market, to develop either a new technology or a new product, and to organize new logistic services).

In formal terms, a meta-model of a DESNET has been proposed (Villa, 2006), where the term 'meta-model' means a model integrating the most important components of a SME network, connected by the critical links and interactions. The meta-model of a DESNET contains the following components (see Figure 1): 
1. an Operation Structure (OS), representing the graph of the logistic connections among the firms. It refers to the graph of interactions linking the enterprises together, through flows of parts, information \& controls, money; each node of this graph is an autonomous enterprise, and plays the role an of individual decision-maker (DM) but included into a group of companion DMs;

2. an Organization Arrangement (OA), describing the management architecture which drives the DESNET behavior (i.e., the DESNET governance), and the information pattern which links the firms together;

3. the Interactions with the Socio-Economic Environment (ISEE) within which the DESNET operates, that means the interactions with the markets of materials and products, and with the financial market and the labor market. In principle, its scope is to make as strong as possible the presence of the industrial network in the markets of final products, labor, finance, etc.,

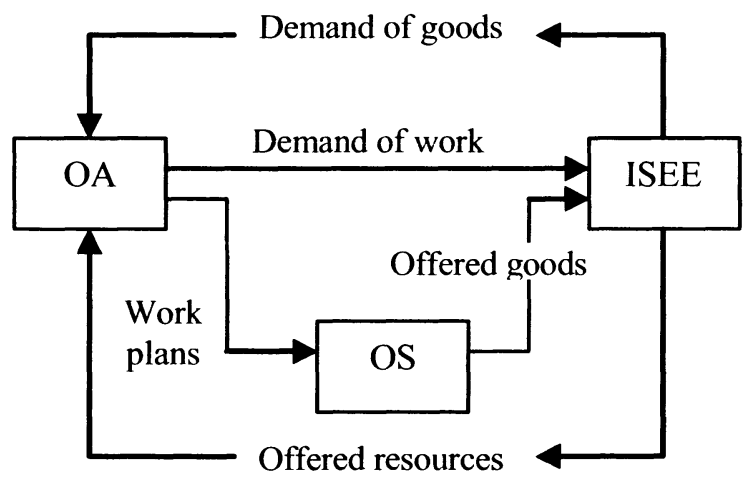

Figure 1 - The conceptual model of a DESNET

To make the above described meta-model an analysis tool, each component must be formally described by specific models, either descriptive or prescriptive.

\section{COLLECTED DATA FOR THE ANALYSIS}

A useful representation of each meta-model component can be obtained by considering qualitative and quantitative descriptions of existing SME networks, by collecting public data and information on their main features and characteristics, and then by using these data/information representations as examples for an analysis based on comparisons among the several industrial bodies. In the CODESNET approach, since the scope is to offer information both to industrial people and to university researchers, the descriptions of the components must be stated in a standardized form, which must summarize the most important analysis drivers and performance indicators. Two standardized formats represent a way for a conceptual organization of data and information. They have been called V-LIB and V-LAB:

- V-LIB (Virtual Library): scientific reports and papers presenting networks' models and discussing problems of network design and management; 
- V-LAB (Virtual Laboratory): descriptions of existing SME networks, each one presenting a strong characteristic in either the OS, OA, or ISEE.

Each component of the meta-model has been detailed in three main issues that represent some questions that need an answer in order to give a complete and useful description of the ID. This set of typical main issues, concerning SME network management or evaluation, is selected and used as key-driver in the search within the data archive and the model catalogue. Each main issue plays also the role of "analysis viewpoint" for an industrial user.

The main issues representatives of the meta-model have a central role in the interaction of V-LIB with V-LAB and vice versa. Their central position is evident looking at Table 1.

Depending on which main qualifying attributes of the analyzed enterprise network are recognized in the $\mathrm{V}$-LAB format, either proper models (for network simulation, design or performance evaluation) or methods (for network management) or procedures (for network innovation and skill improvement) can be found in some catalogued scientific papers, summarized in V-LIB formats.

Among all V-LIB and V-LAB documents available on CODESNET web portal, a subset of particularly interesting and useful papers has been selected and analyzed. The selection has been done on the strength of the importance and the completeness of information and data available on the documents.

Table 2 and Table 3 show a conceptual organization of the information collected in the V-LIB and V-LAB formats, respectively.

In Table 2, for each selected V-LIB, the numbered Main Issues identified in the scientific paper are described. In the fourth column the type of paper content is specified; the notation introduced is (A) for algorithms and methods, (B) for case study, (C) for survey. In the other columns, the most relevant topics approached in the paper are specified and the related V-LABs are listed.

From the other side, it is also important to have a reverse procedure to connect enterprises networks to one or more papers described through the V-LIB. This reverse path is shown in Table 3, where the list of the selected V-LAB formats is shown. Each V-LAB is associated to one or more CODESNET Main Issues and is summarized by its most qualifying attributes.

These two tables describe the connections between V-LAB and V-LIB lists, which are proposed to the end user when analyzing elements of either the Virtual Laboratory or the Virtual Library. This work has required a logical procedure, which will be explained in Sections 4 and 5 in order to facilitate the understanding and the analysis. 
Table 1 - V-LIB and V-LAB correspondence with CODESNET main issues

\begin{tabular}{|c|c|c|c|}
\hline V-LAB & \multirow{2}{*}{\multicolumn{2}{|c|}{ CODESNET Main issues }} & V-LIB \\
\hline $\begin{array}{c}\text { Main attributes of } \\
\text { an enterprise } \\
\text { network }\end{array}$ & & & Main topics \\
\hline \multirow{3}{*}{$\begin{array}{ll}\text { a. } & \text { Type } \\
\text { b. } & \text { Logistics }\end{array}$} & \multirow{3}{*}{ OS } & $\begin{array}{ll}\text { 1. how production } \\
\text { opcrations \& volumes are } \\
\text { distributed among the } \\
\text { cnterprises }\end{array}$ & \multirow{3}{*}{ Model } \\
\hline & & $\begin{array}{l}\text { 2. which different skills are } \\
\text { cmployed in the different } \\
\text { enterprises }\end{array}$ & \\
\hline & & $\begin{array}{l}\text { 3. which logistic network is } \\
\text { used }\end{array}$ & \\
\hline \multirow{3}{*}{$\begin{array}{ll}\text { c. } & \text { Leading } \\
& \text { firms } \\
\text { d. Governance }\end{array}$} & \multirow{3}{*}{$\mathrm{OA}$} & $\begin{array}{llr}4 . & \text { how management } \\
& \text { responsibilitics are } \\
\text { attributed to each } & \text { are } \\
\text { cnterprise and how } \\
\text { information } & \text { are } \\
\text { transferred \& managed }\end{array}$ & \multirow{3}{*}{$\begin{array}{l}\text { Organizational } \\
\text { chart }\end{array}$} \\
\hline & & $\begin{array}{l}\text { 5. how internal agrecments, } \\
\text { or control mechanisms, } \\
\text { are negotiated }\end{array}$ & \\
\hline & & $\begin{array}{l}\text { which organization chart } \\
\text { or coordination strategy } \\
\text { is selected to assure best } \\
\text { efficiency/cffectiveness }\end{array}$ & \\
\hline \multirow{3}{*}{$\begin{array}{ll}\text { c. } & \begin{array}{l}\text { Personnel } \\
\text { skill level }\end{array} \\
\text { f. Innovation } \\
\text { programs }\end{array}$} & \multirow{3}{*}{ ISEE } & $\begin{array}{l}\text { 7. how commercial } \\
\text { agrements with extcrnal } \\
\text { bodics are negotiated for } \\
\text { max profit for the } \\
\text { network }\end{array}$ & \multirow{3}{*}{$\begin{array}{ll}\text { III. } & \begin{array}{l}\text { Skill } \\
\text { competence } \\
\text { profile }\end{array} \\
\text { IV. } & \begin{array}{l}\text { Innovation } \\
\text { plans }\end{array}\end{array}$} \\
\hline & & $\begin{array}{llr}\text { 8. } & \text { how a network } \\
\text { innovation program is } \\
\text { decided by partners (and } \\
\text { negotiated r with } \\
\text { financicrs) }\end{array}$ & \\
\hline & & $\begin{array}{l}\text { 9. which dynamic cvolution } \\
\text { of the network can be } \\
\text { forccast }\end{array}$ & \\
\hline
\end{tabular}

\section{LINKING V-LIBS AND V-LABS}

In order to obtain an accurate association between V-LIBs and V-LABs, a preliminary analysis and classification of V-LIBs is useful. This V-LIBs evaluation is performed according to the informative levels summarized in Figure 2:

1. identifying the main issues among the nine questions;

2. analyzing the paper content, understanding which features the paper discusses;

3. evaluating the completeness and usefulness of information and of data;

4. if they are adequate, the V-LIB can be inserted in the data base; otherwise, the considered V-LIB has to be improved. 
Table 2 - Selected list of V-LIB formats, with the most relevant topics

\begin{tabular}{|c|c|c|c|c|c|c|c|c|c|}
\hline & & & & & \multirow[b]{3}{*}{$\begin{array}{l}\text { Related } \\
\text { V-LAB }\end{array}$} \\
\hline & & & & & \multicolumn{4}{|c|}{ Most relevant TOPICS } & \\
\hline$\#$ & $\begin{array}{l}\text { Selected } \\
\text { V-LIB list }\end{array}$ & Authors & $\begin{array}{c}\text { Main } \\
\text { Issue }\end{array}$ & $\begin{array}{c}\text { Type } \\
\text { of } \\
\text { paper }\end{array}$ & $\begin{array}{c}\text { I. } \\
\text { model }\end{array}$ & $\begin{array}{c}\text { II. } \\
\text { Organiz. } \\
\text { chart }\end{array}$ & $\begin{array}{l}\text { III. Skill } \\
\text { competence } \\
\text { profile }\end{array}$ & $\begin{array}{c}\text { NV. } \\
\text { Innovation } \\
\text { plans }\end{array}$ & \\
\hline 9 & $\begin{array}{l}\text { Collaborative } \\
\text { networks: a new } \\
\text { scientific discipline }\end{array}$ & $\begin{array}{l}\text { Camarinha- } \\
\text { Matos L. M., } \\
\text { Afsarmanesh } \mathrm{H} \text {. }\end{array}$ & 4,6 & c & & $x$ & & & $\begin{array}{c}7,8,29, \\
35\end{array}$ \\
\hline 12 & $\begin{array}{l}\text { Competence } \\
\text { Profiling and } \\
\text { Problem Solving } \\
\text { in Virtual } \\
\text { Networks }\end{array}$ & $\begin{array}{l}\text { Edelmann } \mathrm{C} \text {., } \\
\text { Wagner } \mathrm{K} .\end{array}$ & 2 & c & & & $x$ & & $\begin{array}{c}7,9,29 \\
38,53 \\
54\end{array}$ \\
\hline 13 & $\begin{array}{l}\text { Constructing a } \\
\text { typology for } \\
\text { networks of firms } \\
\text { based on activities } \\
\text { complementarity } \\
\text { and competences } \\
\text { similarity } \\
\end{array}$ & $\begin{array}{l}\text { Burlat } P ., \\
\text { Besombes B., } \\
\text { Deslandres V. }\end{array}$ & 1 & B & & & $x$ & & $\begin{array}{l}29,37, \\
38,50, \\
53,54\end{array}$ \\
\hline 32 & $\begin{array}{l}\text { Framework for } \\
\text { outsourcing } \\
\text { manufacturing: } \\
\text { strategic and } \\
\text { operational } \\
\text { implications }\end{array}$ & Momme J. & 5,7 & A & $x$ & & & & 13,34 \\
\hline 33 & $\begin{array}{l}\text { A framework for } \\
\text { comparing } \\
\text { outsourcing } \\
\text { strategies in multi- } \\
\text { layered supply } \\
\text { chains } \\
\end{array}$ & $\begin{array}{l}\text { Abdel-Malek L., } \\
\text { Kullpattaranitun } \\
\mathrm{T} \text {. }\end{array}$ & 5,7 & A & $\mathrm{x}$ & & & & $\begin{array}{l}13,34 \\
66,68\end{array}$ \\
\hline
\end{tabular}

Table 3 - Selected list of V-LAB formats, with the most qualifying attributes

\begin{tabular}{|c|c|c|c|c|c|c|c|c|c|}
\hline \multirow[b]{2}{*}{$\#$} & \multirow[b]{2}{*}{$\begin{array}{l}\text { selected } \\
\text { V-LAB list }\end{array}$} & \multirow[b]{2}{*}{$\begin{array}{l}\text { Main } \\
\text { Issue }\end{array}$} & \multicolumn{6}{|c|}{ Most qualifying attributes } & \multirow[b]{2}{*}{$\begin{array}{c}\text { Related } \\
\text { V-LIB }\end{array}$} \\
\hline & & & (a) Type & $\begin{array}{c}\text { (b) } \\
\text { Logistics }\end{array}$ & $\begin{array}{c}\text { (c) } \\
\text { Leading } \\
\text { firms }\end{array}$ & $\begin{array}{c}\text { (d) } \\
\text { Governance }\end{array}$ & $\begin{array}{l}\text { (e) Personnel } \\
\text { skill level }\end{array}$ & $\begin{array}{c}\text { (f) } \\
\text { Innovation } \\
\text { programs }\end{array}$ & \\
\hline 7 & $\begin{array}{l}\text { District 21 - } \\
\text { Suzzara }\end{array}$ & $\begin{array}{l}2,6 \\
8\end{array}$ & $\begin{array}{l}\text { 2-stage } \\
\text { SC } \\
3500 \\
\text { SMEs }\end{array}$ & & & $\begin{array}{l}\text { Political } \\
\text { committee }\end{array}$ & $\begin{array}{l}\text { skills in } \\
\text { steeling and } \\
\text { manufacturing } \\
\text { activities }\end{array}$ & $\begin{array}{l}\text { collaboration } \\
\text { with } \\
\text { universities }\end{array}$ & $\begin{array}{c}9,12, \\
34,35, \\
36,53, \\
72\end{array}$ \\
\hline 13 & \begin{tabular}{|l} 
Automotive \\
District \\
Stuttgart
\end{tabular} & $\begin{array}{l}5,7 \\
8\end{array}$ & multi-agent & outsourcing & \begin{tabular}{|l|}
$2-3$ \\
leading \\
firm \\
(OEM) \\
\end{tabular} & & & & $\begin{array}{l}16,32, \\
33,52, \\
56,96\end{array}$ \\
\hline 34 & \begin{tabular}{|l|} 
Shoes \\
District of \\
Verona
\end{tabular} & $\begin{array}{l}1,5 \\
8,9\end{array}$ & \begin{tabular}{|l|} 
Flexible \\
SC, \\
524 SMEs
\end{tabular} & outsourcing & & $\begin{array}{l}\text { Support } \\
\text { agency }\end{array}$ & & $\begin{array}{l}\text { collaboration } \\
\text { with res. } \\
\text { centre, R\&D }\end{array}$ & $\begin{array}{l}32,33, \\
36,69, \\
72,81\end{array}$ \\
\hline 35 & \begin{tabular}{|l|} 
BIO cluster \\
district - \\
Bioindustry \\
Park \\
\end{tabular} & $\begin{array}{l}4,6 \\
8,9\end{array}$ & \begin{tabular}{|l|} 
Scientific \\
park \\
344 \\
companies \\
\end{tabular} & & & $\begin{array}{l}\text { Regional } \\
\text { system } \\
\text { integrator }\end{array}$ & \begin{tabular}{|l|} 
importance of \\
high \\
competence, \\
skills \\
\end{tabular} & innovation & $\begin{array}{c}4,9,36 \\
65,72, \\
76,103 \\
107 \\
\end{array}$ \\
\hline 37 & Evonet & $\begin{array}{l}1,2 \\
8\end{array}$ & $\begin{array}{l}\text { flexible SC } \\
6 \text { SMEs }\end{array}$ & & & $\begin{array}{l}\text { managerial } \\
\text { center }\end{array}$ & $\begin{array}{l}\text { different skills } \\
\text { in mechanical } \\
\text { engineering }\end{array}$ & & $\begin{array}{l}13,20, \\
27,34, \\
48,69, \\
70,76, \\
77,96\end{array}$ \\
\hline
\end{tabular}




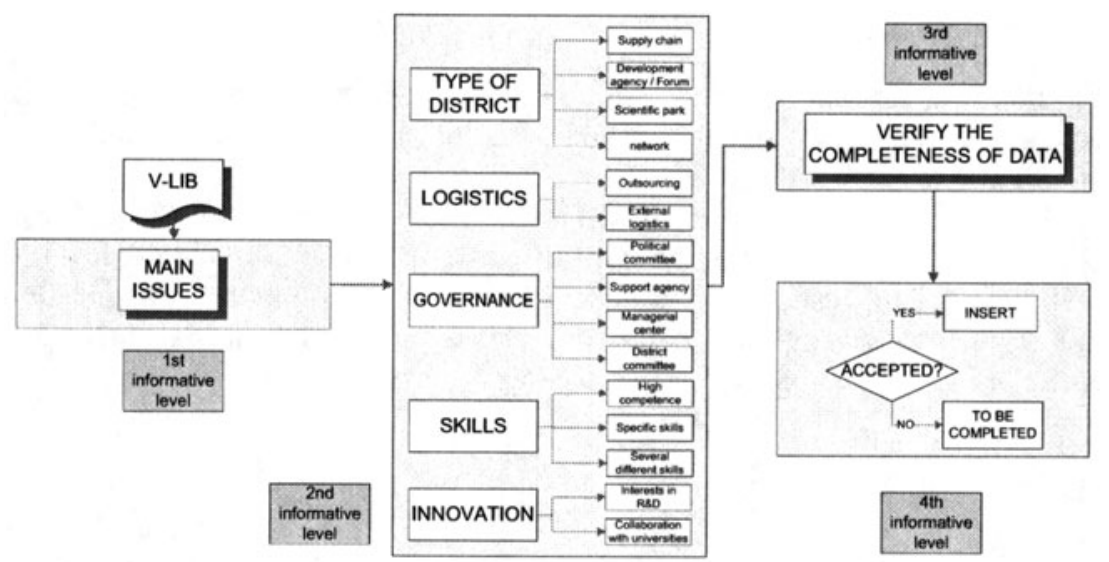

Figure 2 - Steps necessary for V-LIB classification

The most qualifying attributes of each industrial network have been extracted from each selected V-LAB (Table 3). From this information, it is possible to understand the characterizing features of each district. Combining together Tables 2 and 3 , it is possible to find for each industrial network its related V-LIBs, looking at the weak and strong points of the district, and associating them proper articles included in the list of the selected V-LIBs.

This association is performed in three steps: 1) consider only the V-LIBs belonging to the main V-LAB issues; 2) among the filtered list of V-LIBs, search for scientific papers having appropriate topics, according to the V-LIB classification; 3) analyze the content of each paper to verify the association.

Let us consider, for instance, the Shoes District of Verona (V-LAB n. 34). It is a flexible supply chain, composed by 524 SMEs. From the logistic point of view, outsourcing is used for the management of the distribution. Coordination is assured by a support agency. There is a relevant cooperation with Universities and other research centers; so, an interest in R\&D comes out from this information. The main issues associated to this district are the categories $1,5,8$ and 9.

The first step for the association consists in filtering V-LIBs, using the four categories the V-LAB belongs to. Among this filtered list, look for scientific papers with appropriate topics. In the Shoes District case, its V-LAB shows as interesting topics: "Model", "Organizational Chart" and "Innovation Plans". Regarding the VLIB classification, it is necessary to look for papers that relate to: supply chain, outsourcing, support agency, interests in R\&D and collaboration with universities. From the list of V-LIBs belonging to the main issues 1, 5, 8, 9 and concerning these topics, some appropriate papers are associated to the Shoes District. Particularly (for the complete list of V-LIBs, see http://www.codesnet.polito.it):

V-LIB n. 32-33: concerning outsourcing;

V-LIB n. 36-81: concerning R\&D and innovation;

V-LIB n. 69-72: about coordination and collaboration in a supply chain. 


\section{CONCLUSIONS}

This study provides a logical procedure useful to arrange the available information on industrial networks and to facilitate the integration between actual industrial systems and scientific studies.

Even though the data collected within CODESNET Project are constrained to be public (in order to allow their open diffusion through Internet), their analysis could produce useful suggestions. As a matter of fact, the outcome of this approach could be a starting point for the performance evaluation of IDs management and for benchmark identification.

\section{REFERENCES}

1. Abu-Suleiman A, Boardman B, Priest JW. A Framework for an Integrated Supply Chain Performance Management System. International Journal of Production Research, 2005; 43(15), 3287-3296.

2. Akif JC, Blanc S, Ducq Y. Comparison of methods and frameworks to evaluate the performance of supply chains, 4th International Workshop on performance measurement implementation of performance measurement systems for supply chains, Bordeaux, June 27-28, 2005.

3. Alberti F. The governance of industrial districts: a theoretical footing proposal. Liuc Papers $\mathrm{n}$. 82, Serie Piccola e Media Impresa 5, January 2001.

4. Albino V, Garavelli AC, Schiuma G. Knowledge transfer and inter-firm relationships in industrial districts: the role of the leader firm. Technovation, 1999; 19: 53-63.

5. Albino V, Kühtz S. Enterprise input-output model for local sustainable development - The case of a tiles manufacturer in Italy, Resources, Conservation and Recycling 2004; 41: 165-176.

6. Becattini G. The Marshallian industrial district as a socio-economic concept. In: F. Pyke, G. Becattini and W. Sengenberger, Industrial Districts and inter-firm cooperation in Italy, Geneva: International Institute for Labour Studies, 1990.

7. Brewer PC, Speh TW. Using the Balanced Scorecard to measure supply chain performance, Journal of Business Logistics, 2000; 21, 1.

8. Fabiani S, Pellegrini G. Un'analisi quantitativa delle imprese nei distretti industriali italiani: redditività, produttività e costo del lavoro. L'Industria, vol XIX, 1998; 4: 811-831.

9. Kaplan RS, Norton DP. Putting the Balanced Scorecard to Work, Harvard Business Review, September - October 1993, 1-15.

10. Kaplan RS, Norton DP. The Balanced Scorecard - Measures that Drive Performance, Harvard Business Review, January - February 1992, 71-79.

11. Kaplan RS, Norton DP. The Balanced Scorecard: Translating Strategy into Action, Harvard Business School Press, 1996.

12. Klejinen JPC, Smits MT. Performance metrics in supply chain mangement. Journal of the Operational Research Society 2003; 54, 5, 507-514.

13. Lin C, Chow WS, Madu CN, Kuei CH, Yu PP. A structural equation model of supply chain quality management and organizational performance. Int. J. of Production Economics, 2005; 96: 355-365.

14. Molina-Morales FX. European industrial districts: Influence of geographic concentration on performance of the firm. Journal of International Management, 2001; 7: 277-294.

15. Paniccia I. The performance of IDs. Some insights from the Italian case. Human Systems Management, 1999; 18: 141-159.

16. Picard PM, Toulemonde E. Regional asymmetries: economies of agglomeration versus unizoned labor markets, Regional Sciences and Urban Economics 2003; 33: 223-249.

17. Rosenfeld S. Industrial strength strategies: regional business clusters and public policy. Aspen Institute, Washington DC, 1995.

18. Signorini LF. The price of Prato, or measuring the ID effect. Papers in Regional Science, 1994; 73: 369-392.

19. Supply Chain Council. Manual of Supply-Chain Operations Reference-model: SCOR 8.0, 2006.

20. Verwaal E, Hesselmans M. Drivers of Supply Network Governance: An Explorative Study of the Dutch Chemical Industry, European Management J, 2004; 22: 442-451.

21. Villa A. Reinforcing Industrial Districts: Need for a Structured Approach. Proceedings of INCOM 2006, 12th IFAC/IFIP Symposium on INformation COntrol problems in Manufacturing, 2006. 